\title{
Kandungan Coliform dan Salmonella Pelet Limbah Penetasan dengan Penambahan Bentonit dan Lama Penyimpanan yang Berbeda
}

\section{(The Number of Coliform and Salmonella of Hatchery Waste Pellets with Addition of Betonites and Different Time of Storage)}

\author{
Khoiruddin M, Sulistiyanto B, Sumarsih S \\ Fakultas Peternakan dan Pertanian, Universitas Diponegoro, Semarang \\ dudinsguns@gmail.com
}

\begin{abstract}
The experiment to study an effect of bentonite addition in the pelletizing process of hatchery wastes on Coliform and Salmonella number of pellet products after storage in different times. The experiment was conducted at the Feed Technology Laboratory, Faculty of Animal and Agriculture Sciences, Diponegoro University. Bentonite has a property of adsorbing substances and has a larger particle pore size than bacteria, thus enabling the occurrence of bacterial adsorption into the bentonite structure and inhibiting the growth of bacteria. Therefore, bentonite is expected to elongate the life time of pellet products during storage. The experiment was conducted by Completely Randomized Design (CRD) with factorial pattern $2 \times 3$. The first factor was the level of bentonite; 0 and 3\%, and the second factor was time of storage; 4, 8 and 12 weeks with three replications of each treatment combination. The results showed that the addition of 0 and 3\% bentonite had no significant effect $(\mathrm{P}>0.05)$ on the number of Coliform in the hatchery wastes pellets after storage. Moreover, Salmonella in the hatchery waste pellets was negative. It could be concluded that pelleting process was able to suppress the number of Coliform and Salmonella of hatchery waste pellets until a critical limit of safety number, but the addition of bentonite was not effective on inhibiting the growth of pathogenic bacteria during storage.
\end{abstract}

Key Words: Bentonite, Coliform, Salmonella, Pellet, Hatching Waste

\begin{abstract}
ABSTRAK
Penelitian untuk mengkaji pengaruh penambahan bentonit pada proses peleting limbah penetasan terhadap kandungan Coliform dan Salmonella dari produk pelet setelah penyimpanan pada waktu yang berbeda dilakukan di Laboratorium Teknologi Pakan, Fakultas Peternakan dan Pertanian, Universitas Diponegoro. Bentonit memiliki khasiat zat pengabsorpsi dan memiliki ukuran pori partikel lebih besar daripada bakteri sehingga memungkinkan terjadinya absorpsi bakteri ke dalam struktur bentonit dan menghambat pertumbuhan bakteri. Oleh karena itu, diharapkan bisa memperpanjang umur produk pelet selama penyimpanan. Penelitian dilakukan dengan rancangan acak lengkap (RAL) dengan pola faktorial $2 \times 3$. Faktor-faktor tersebut adalah tingkat bentonit 0 dan 3\%, serta waktu penyimpanan 4, 8 dan 12 minggu dengan 3 ulangan dari masing-masing kombinasi perlakuan. Hasil penelitian menunjukkan bahwa penambahan bentonit 0 dan 3\% tidak berpengaruh nyata $(\mathrm{P}>0,05)$ terhadap jumlah Coliform pada pelet limbah penetasan setelah penyimpanan. Salmonella dalam pelet limbah penetasan pasca-peyimpanan negatif. Dapat disimpulkan bahwa proses peleting mampu menekan kandungan Coliform dan Salmonella pada pelet limbah penetasan sampai pada ambang batas aman, namun penambahan bentonit belum efektif menekan pertumbuhan bakteri patogen selama peyimpanan.
\end{abstract}

Kata Kunci: Bentonit, Kandungan Coliform, Salmonella, Pelet, Limbah Penetasan 


\section{PENDAHULUAN}

Limbah penetasan merupakan hasil samping industri penetasan (hatchery) dan diharapkan dapat dimanfaatkan sebagai bahan pakan alternatif untuk pakan ternak. Produksi salah satu industri penetasan yang memproduksi 4,2 juta ekor day old chick (DOC) per minggu menghasilkan 52,50 ton limbah penetasan (Sungkowo 2016). Limbah penetasan yang dihasilkan oleh industri penetasan (hatchery) dapat menimbulkan pencemaran lingkungan seperti polusi udara yang disebabkan oleh bau menyengat dari limbah industri penetasan serta cemaran mikroorganisme yang mengganggu kesehatan manusia, untuk itu perlu ditangani dengan cara yang tepat sehingga dapat memberi manfaat lain berupa keuntungan ekonomis dari penanganan tersebut. Penelitian pendahuluan Sulistiyanto (2015) mencatat kandungan nutrisi limbah penetasan yang terdiri cangkang telur, telur infertil, embrio gagal menetas dan DOC afkir memiliki kandungan air $\pm 40 \%$, protein kasar $\pm 20 \%$ dan lemak kasar $\pm 9 \%$. Kandungan air dan protein yang tinggi ditengarai merupakan faktor pendukung pertumbuhan mikroorganisme sehingga limbah mudah rusak, busuk dan berbau (Wardana et al. 2016). Kontaminasi bakteri patogen pada pakan dapat dikendalikan dengan menerapkan sistem pengolahan menggunakan bahan kimia dan bahan pengikat (Maryam 2006).

Bentonit merupakan lempeng mineral yang berasal dari abu vulkanik yang mengandung montmorilonite lebih dari 85\% (Retnani et al. 2011). Bentonit memiliki sifat menyerap zat di sekitarnya yang berupa larutan, gas dan penukar kation dan biasa digunakan sebagai bahan penyerap dalam bidang peternakan, perikanan maupun pertanian (Aziz 2009). Bentonit memiliki kemampuan mengembang, memiliki ukuran pori partikel lebih besar daripada bakteri, memungkinkan terjadi absorbsi bakteri ke dalam bentonit sehingga mampu mencegah perkembangan bakteri (Kamland 2010). Retnani et al. (2009) melaporkan bahwa penambahan bentonit dalam pakan bentuk pelet dapat menurunkan kadar air $(10,69 \%)$ dan meningkatkan ketahanan pelet. Bentonit merupakan perekat yang dipergunakan di industri pakan untuk meningkatkan kualitas pelet (Thomas et al. 1998). Bentonit sering digunakan untuk mengurangi cemaran berbagai mikotoksin dan beberapa zat antinutrisi yang terkandung dalam bahan pakan (Maryam 2006).

Pelet adalah ransum yang dibuat dengan menggiling bahan baku yang kemudian dipadatkan menggunakan die dengan bentuk, diameter, panjang dan derajat kekerasan yang berbeda (Pond et al. 1995). Keuntungan pakan bentuk pelet adalah meningkatkan konsumsi dan efisiensi pakan, meningkatkan kadar energi metabolisme, membunuh bakteri patogen, menurunkan jumlah pakan yang tercecer, memperpanjang lama penyimpanan, menjamin keseimbangan zat nutrisi pakan dan mencegah oksidasi vitamin (Suryadi et al. 2014).

Bakteri kelompok Coliform meliputi semua bakteri berbentuk batang, Gram negatif, tidak membentuk spora dan dapat memfermentasi laktosa dengan memproduksi gas dan asam pada suhu $37^{\circ} \mathrm{C}$ dalam waktu kurang dari 48 jam. Bakteri Coliform sebagai indikator kualitas air, makin sedikit kandungan Coliform, artinya kualitas air semakin baik (SNI 2008). Suwito (2010) menyatakan bahwa 6-7\% bahan pakan berisiko tercemar Salmonella dan Coliform. Pakan yang terkontaminasi Coliform dapat menyebabkan diare yang akut pada ternak (Jasmadi et al. 2014). Pemberian bentonit ke dalam pakan dapat mengurangi total bakteri (Nowakowlcz-Debek \& Wlazlo 2011).

Salmonella adalah salah satu dari 14 genus bakteri dari keluarga Enterobacteriaceae, Salmonella berbentuk batang pendek, Gram negatif, aerob/fakultatif, tidak berspora, bergerak (peritrichous) tidak bergerak (atrichous) (Poernomo 2004). Produk olahan hasil ikutan unggas sebagai bahan pakan harus negatif pada uji bakteri Salmonella (SNI 2014). Pakan yang terkontaminasi Salmonella dapat menyebabkan penyakit dengan gangguan 
pada bagian saluran pencernaan dan juga saluran reproduksi (ovarium dan oviduk) (HaraKudo et al. 2001). Menurut Suwito (2010) salah satu hal yang diperlukan agar pakan bebas Salmonella harus dimulai dari pemilihan bahan baku dan perlakuan panas yang efektif dalam proses pembuatan pakan dan mencegah kontaminasi ulang terhadap pakan yang sudah jadi. Perlakuan peleting dan penambahan bentonit diharapkan dapat memperbaiki kualitas limbah penetasan, mampu mempertahankan kualitas pelet limbah penetasan selama penyimpanan. Tujuan penelitian ini adalah untuk mengetahui pengaruh penambahan bentonit pada proses peleting limbah penetasan terhadap kandungan Coliform dan Salmonella pelet pada lama penyimpanan yang berbeda.

\section{MATERI DAN METODE}

Penelitian dilaksanakan pada bulan Oktober sampai dengan Desember 2016 di Laboratorium Teknologi Pakan, Fakultas Peternakan dan Pertanian, Universitas Diponegoro, Semarang. Materi dalam penelitian adalah limbah penetasan (cangkang telur, telur gagal menetas dan DOC afkir) serta mineral binder berupa bentonit.

Tahap pengolahan diawali dengan pemisahan masing-masing komponen limbah. Komponen tersebut terdiri atas 10\% DOC afkir atau mati, 30\% cangkang telur dan $60 \%$ telur gagal tetas. Komponen limbah penetasan kemudian dihaluskan menggunakan blender. Komponen yang sudah halus dicampur hingga homogen kemudian ditambah onggok sebanyak 10\% (B/B) dari total berat campuran limbah. Limbah dan onggok kemudian dicampur hingga homogen kemudian ditambahkan bahan aditif berupa bentonit sebanyak 3\% (B/B) dari total berat limbah yang diolah. Proses selanjutnya dilakukan pengukusan atau conditioning pada suhu $80-90^{\circ} \mathrm{C}$ selama 15 menit kemudian dilakukan pencetakan pelet atau peleting dengan menggunakan ekstruder dengan spesifikasi Gear Box 1:30 ukuran 50 dengan ukuran diameter lubang cetakan $6 \mathrm{~mm}$ dan panjang pelet $3 \mathrm{~cm}$. Pelet yang sudah dicetak, dikeringkan menggunakan mesin pengering dengan suhu 40$45^{\circ} \mathrm{C}$ selama 24 jam sampai kadar air pelet berkisar antara $12-15 \%$. Pelet yang sudah kering kemudian disimpan dalam plastik yang ditutup rapat dengan lama penyimpanan yang berbeda yaitu $0,4,8$ dan 12 minggu pada suhu kamar $\left(25^{\circ} \mathrm{C}\right.$ dan kelembapan $\left.\pm 70 \%\right)$.

Tahap selanjutnya yaitu pengujian Coliform. Uji Coliform diawali dengan menyiapkan empat tabung reaksi yang telah disterilkan dan memberi tanda pada masing masing tabung dengan tanda $10^{-1}$ sampai dengan $10^{-4}$, kemudian masing-masing tabung diisi dengan $9 \mathrm{cc}$ $\mathrm{NaCl}$ 0,85 steril secara aseptis, sampel pelet dihaluskan dan ditimbang seberat $1 \mathrm{~g}$ kemudian dimasukan ke dalam tabung reaksi dengan label $10^{-1}$ dan dihomogenkan. Setelah homogen diambil $1 \mathrm{cc}$ dari tabung tersebut, dimasukkan ke dalam tabung reaksi dengan label $10^{-2}$ dan dihomogenkan. Sampel diambil $1 \mathrm{cc}$ dari tabung tersebut, dimasukkan ke dalam tabung reaksi dengan label $10^{-3}$ dan dihomogenkan. Sampel diambil 1 cc terakhir dari tabung tersebut dan dimasukkan pada tabung reaksi dengan label $10^{-4}$ dan dihomogenkan. Media agar disiapkan pada empat cawan petri yang telah disterilkan dan diberi label tanda $10^{-2}$ sampai dengan $10^{-4}$ dan 1 blangko. Masing-masing pipet digunakan untuk mengambil 0,1 cc dan dituangkan ke dalam cawan petri sesuai dengan label yang

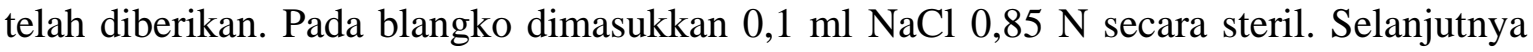
ditambahkan \pm 15 cc chromocul coliform agar (CCA) pada suhu $40-42^{\circ} \mathrm{C}$ dan dihomogenkan, didiamkan sampai agar membeku. Media yang diberi label diinkubasi dalam inkubator pada suhu $37^{\circ} \mathrm{C}$ selama $18-24$ jam. Koloni yang tumbuh pada media untuk setiap pengenceran dihitung dengan mengikuti metode penghitungan standar plate count (SPC).

Uji Salmonella dilakukan dengan cara menghaluskan $1 \mathrm{~g}$ sampel yang telah halus serta dilarutkan ke dalam media brain heart infusion broth (BHIB) sampai larut sempurna. Sampel yang sudah dilarutkan diinokulasikan menggunakan jarum OSE pada media 
MacConkey, selanjutnya diinkubasikan pada suhu $37^{\circ} \mathrm{C}$ selama $18-24$ jam dalam inkubator. Koloni yang tumbuh pada media diamati, koloni Salmonella pada media MacConkey memiliki ciri-ciri berbentuk bulat, berwarna putih, tepi berlobang, cembung dan konsistensi lunak. Koloni yang memiliki ciri tersebut kemudian diambil dengan jarum OSE dan diinokulasikan pada media uji biokimia. Media uji biokimia diinkubasi selama 17-24 jam dalam inkubator. Kemudian untuk membaca hasil uji biokimia maka ditambahkan lima tetes Kovack's pada media indol, lima tetes Alfanaphtol 5\% dan KOH keratin 40\% masing masing lima tetes pada media Voges-Proskauer (VP) dan ditambahkan lima tetes reagen Methyl Red (MR) pada media MR. Salmonella dinyatakan positif apabila pada media uji indol tidak terbentuk cincin merah, motil terbentuk tumbuh menyebar di sekitar bekas tusukan, glukosa terbentuk warna kuning serta pada tabung durham terbentuk gelembung udara, laktosa tetap merah, maltosa terbentuk warna kuning, manitol terbentuk warna kuning dan pada tabung durham terbentuk gelembung udara, urea berwarna kuning, MR terbentuk warna merah dan simon sitrat tetap hijau.

\section{Analisis data}

Penelitian dilakukan dengan menggunakan rancangan acak lengkap (RAL) pola faktorial $2 \times 3$ (tingkat bentonit 0 dan 3\% dengan lama penyimpanan 4, 8 dan 12 minggu) dengan ulangan 3 kali. Analisis data menggunakan analisis ragam dengan taraf signifikansi 5\% dan membandingkan $\mathrm{F}$ hitung dengan $\mathrm{F}$ tabel untuk mengetahui adanya pengaruh perlakuan.

\section{HASIL DAN PEMBAHASAN}

\section{Kandungan Coliform}

Rataan kandungan Coliform pelet limbah penetasan dengan persentase bentonit 0 dan $3 \%$ yang disimpan selama 4, 8 dan 12 minggu dapat dilihat pada Tabel 1. Hasil analisis ragam menunjukkan bahwa tidak terdapat interaksi $(\mathrm{P}>0,05)$ antara penambahan bentonit dengan lama penyimpanan berbeda terhadap kandungan Coliform pada pelet limbah penetasan selama penyimpanan. Hal ini menunjukkan bahwa tidak terdapat perbedaan kandungan bentonit antara penambahan bentonit dengan lama penyimpanan berbeda.

Berdasarkan hasil analisis ragam perlakuan penambahan bentonit menunjukan tidak berpengaruh nyata $(\mathrm{P}>0,05)$ terhadap kandungan Coliform pada pelet limbah penetasan selama penyimpanan. Hal ini dimungkinkan karena bentonit belum dilakukan aktivasi terlebih dahulu pada saat proses pengolahan sehingga fungsi bentonit tidak optimal. Hal ini sesuai pendapat Retnani et al. (2009) bahwa bentonit sebelum digunakan harus mengalami pengaktifan terlebih dahulu karena dalam keadaan awal hanya memiliki kemampuan absorpsi yang rendah. Menurut Sahara (2011), bentonit yang diaktivasi panas menunjukkan kapasitas absorpsi yang lebih besar daripada bentonit sebelum diaktivasi. 
Tabel 1. Kandungan Coliform pelet limbah penetasan

\begin{tabular}{|c|c|c|c|c|}
\hline \multirow{3}{*}{ Penambahan bentonit } & \multicolumn{3}{|c|}{ Lama penyimpanan (minggu) } & \multirow{2}{*}{ Rata-rata } \\
\hline & 4 & 8 & 12 & \\
\hline & \multicolumn{4}{|c|}{ 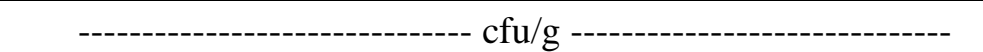 } \\
\hline $0 \%$ & $4,0 \times 10^{6}$ & $6,5 \times 10^{4}$ & $3,3 \times 10^{4}$ & $1,4 \times 10^{6}$ \\
\hline $3 \%$ & $5,7 \times 10^{4}$ & $5,3 \times 10^{4}$ & $4,0 \times 10^{4}$ & $5,0 \times 10^{4}$ \\
\hline Rata-rata & $2,0 \times 10^{6}$ & $5,9 \times 10^{4}$ & $3,6 \times 10^{4}$ & \\
\hline
\end{tabular}

CV 38\%, analisis variasi dengan transformasi $\log (10)$ dan uji F pada taraf 5\%

Berdasarkan hasil analisis ragam perlakuan lama penyimpanan yang berbeda menunjukan tidak berpengaruh nyata $(\mathrm{P}>0,05)$ terhadap kandungan Coliform pada pelet limbah penetasan selama penyimpanan. Hal ini dikarenakan sebelum dilakukan penyimpanan pelet dalam kondisi yang baik. Penyimpanan pelet dilakukan dalam kondisi anaerob sehingga terhindar dari kontaminasi lingkungan luar sekaligus menjaga kadar air dan kelembaban udara selama penyimpanan. Kondisi lingkungan yang baik memungkinkan bakteri Coliform tidak dapat bertahan hidup lama. Pertumbuhan jumlah mikroba akan terhenti karena pembatas dari faktor lingkungan atau bahan pangan yang tidak mampu lagi menyediakan kebutuhan yang cukup bagi perkembangbiakan mikroba. Ketiadaan atau kekurangan sumber bahan pangan dapat mempengaruhi pertumbuhan dan perkembangan mikroba hingga pada akhirnya dapat menyebabkan kematian. Nutrisi dibutuhkan mikroba untuk proses metabolisme dan penyediaan bahan sel serta energi. Hal ini sesuai pendapat Dewantari et al. (2016) bahwa mikroorganisme memerlukan suplai nutrisi sebagai sumber energi dan pertumbuhan selnya untuk kelangsungan hidupnya.

Hasil penelitian ditinjau dari segi keamanan pakan menunjukan bahwa pelet limbah penetasan aman digunakan sebagai pakan pada ternak karena masih pada ambang batas aman yaitu pada kisaran $10^{5} \mathrm{cfu} / \mathrm{g}$. Menurut Saray et al. (2014) limbah pangan dengan kandungan total bakteri sampai $10^{5} \mathrm{cfu} / \mathrm{g}$ masih layak dipertimbangkan sebagai bahan pakan.

\section{Kandungan Salmonella}

Identifikasi kandungan Salmonella pelet limbah penetasan dengan persentase bentonit 0 dan 3\% yang disimpan selama 4, 8 dan 12 minggu dapat dilihat pada Tabel 2. Identifikasi kandungan Salmonella menunjukkan hasil negatif.

Tabel 2. Kandungan Salmonella pelet limbah penetasan

\begin{tabular}{lccc}
\hline \hline \multirow{2}{*}{ Penambahan bentonit } & \multicolumn{3}{c}{ Lama penyimpanan (minggu) } \\
\cline { 2 - 4 } & 4 & 8 & 12 \\
\hline $0 \%$ & Negatif & Negatif & Negatif \\
$3 \%$ & Negatif & Negatif & Negatif \\
\hline
\end{tabular}

Hasil identifikasi kandungan Salmonella menunjukkan hasil negatif pada pelet tanpa penambahan bentonit $(0 \%)$ maupun penambahan bentonit $(3 \%)$ pada lama penyimpanan berbeda, ini dikarenakan pelet dalam kondisi yang baik sebelum dilakukan penyimpanan sehingga ketika disimpan dengan lama penyimpanan berbeda tidak terdapat bakteri Salmonella. Hal ini dimungkinkan karena bakteri Salmonella yang terdapat pada material bahan pakan mati pada saat proses pengolahan berlangsung yaitu pada proses 
conditioning. Proses conditioning pada suhu $80-90^{\circ} \mathrm{C}$ selama 15 menit menyebabkan bakteri Salmonella mati. Supardi \& Sukamto (1998) menyatakan bahwa Salmonella akan mati dalam waktu 5 menit pada temperatur $60^{\circ} \mathrm{C}$ atau dalam waktu tiga menit pada temperatur $65,5^{\circ} \mathrm{C}$. Wardana et al. (2016) berpendapat suhu pada proses conditioning berada kisaran suhu pada saat pasteurisasi sehingga mikroba yang dapat merusak pakan dapat berkurang atau mati. Hasil identifikasi Salmonella ditinjau dari segi keamaan pakan menunjukkan pelet limbah penetasan aman diberikan pada ternak. Hal ini karena kandungan Salmonella menunjukkan hasil negatif. Pakan yang aman adalah yang bebas dari kandungan bakteri Salmonella, dengan demikian pelet limbah penetasan tersebut masih aman digunakan sebagai pakan pada ternak (SNI 2014).

\section{KESIMPULAN}

Dapat disimpulkan bahwa proses peleting mampu menekan kandungan Coliform dan Salmonella sampai pada ambang batas aman selama proses penyimpanan, namun penambahan bentonit belum efektif menekan bakteri patogen.

\section{UCAPAN TERIMA KASIH}

Ucapan terima kasih kami sampaikan kepada Laboratorium Teknologi Pakan Fakultas Peternakan dan Pertanian Universitas Diponegoro atas fasilitas yang telah diberikan, Rektor UNDIP atas dukungan dana penelitian melalui hibah kompetitif penelitian mahasiswa, serta kepada Sudarwanto, Yuli Eko, Mega Hardianti, Atiya Inayati, Bima Siswoaji atas kerjasamanya dalam pelaksanaan penelitian.

\section{DAFTAR PUSTAKA}

Aziz M. 2009. Ruang lingkup penelitian pengolahan dan pemanfaatan mineral dalam menunjang prioritas kebutuhan nasional. J Bahan Galian Industri. 5:1-14.

Dewantari NRA, Besung NK, Sampurna IP. 2016. Pengaruh pemberian mineral terhadap jumlah bakteri Eschericia coli dan Coliform pada sapi Bali di dataran tinggi dan dataran rendah. Buletin Vet Udayana. 8:71-78.

Hara-Kudo Y, Sakakibara Y, Konuma H, Sawada T, Kumagai S. 2001. Laying season and egg shell cracks on growth of Salmonella enteritidis in the egg albumen during storage. J Food Prot. 4:1134-1137.

Jasmadi Y, Haryani, Jose C. 2014. Prevalensi bakteri Coliform dan Escherichia coli pada daging sapi yang dijual di pasar tradisional dan pasar modern di Kota Pekanbaru. JOM FMIPA. 1:3139.

Kamland O. 2010. Chemical and mineralogical characterization of the bentonite buffer for the acceptance control procedure in a KBS-3 repository. Stockholm (Sweden): Clay Technology $\mathrm{AB}$.

Maryam R. 2006. Pengendalian terpadu kontaminasi mikotoksin. Wartazoa. 16:21-30.

Nowakowlcz-Debek B, Wlazlo L. 2011. Effect of dietary sodium bentonite supplement on microbial contamination of mink feef. Publish J Environ Stud. 20:1103-1106.

Poernomo JS. 2004. Variasi tipe antigen Salmonella pullorum yang ditemukan di Indonesia dan penyebaran serotipe Salmonella pada ternak. Wartazoa. 14:143-159.

Pond WG, Church DC, Pond KR. 1995. Basic animal nutrition and feeding. New York (US): Jhon Wiley and Sons. 
Retnani Y, Harmiyanti Y, Fibrianti DAP, Herawati L. 2009. Pengaruh penggunaan perekat sintetis terhadap ransum ayam broiler. J Agripet. 9:1-9.

Retnani Y, Herawati L, Khusniati S. 2011. Uji fisik ransum broiler stater bentuk crumble berperekat tepung tapioka, bentonit dan onggok. J Invit Theory Pract. 1:88-97.

Sahara E. 2011. Regenerasi lempung bentonit dengan NH4+ jenuh yang diaktivasi panas dan daya absorpsinya terhadap Cr(III). J Kimia. 5:81-87.

Saray SC, Hosseinkhani A, Janmohammadi H, Zare P, Daghigh KIA. 2014. Thermal and probiotic treatment effects on restaurant waste for incorporation into poultry diet. Int J Recycl Org Waste Agric. 3:71.

SNI. 2008. Metode pengujian cemaran mikroba dalam daging, telur dan susu, serta hasil olahannya. Jakarta (Indonesia): Badan Standardisasi Nasional.

SNI. 2014. Tepung hasil ikutan unggas (poultry by product meal) bahan pakan ternak. Jakarta (Indonesia): Badan Standardisasi Nasional.

Sulistiyanto B. 2015. Pengaruh penambahan zeolit terhadap performans fisik organoleptik hasil olahan limbah penetasan ayam. Laporan penelitian. Semarang (Indonesia): Fakultas Peternakan dan Pertanian, Universitas Diponegoro.

Sungkowo W. 2016. Pengaruh penggunaan tepung limbah penetasan dalam ransum terhadap kecernaan protein, massa protein daging dan rasio efisiensi protein ayam broiler [Skripsi]. [Semarang (Indonesia)]: Universitas Diponegoro.

Supardi I, Sukamto. 1998. Mikrobiologi dalam pengolahan dan keamanan pangan. Bandung (Indonesia): Alumni.

Suryadi U, Hertamawati RT, Bahariawan A. 2014. Penerapan teknologi pelet pada pakan ayam di UD Kharisma Tunggal Jember. J Ilmiah Inovasi. 14:1-5.

Suwito W. 2010. Monitoring Salmonella dan Escheriahia coli dalam pakan ternak. Buletin Peternakan. 34:165-168.

Thomas MT, Vliet V, Van der Poel AFB. 1998. Physicaluality of pelleted animal feed. Contribution of feedstuff components. J Anim Feed Sci Technol. 3:59-78.

Wardana BA, Sulistiyanto B, Sumarsih S. 2016. Pengaruh penambahan zeolit pada proses pelletizing limbah penetasan terhadap kandungan Coliform dan Salmonella produk pelet. J Agripet. 16:42-48.

\section{DISKUSI}

\section{Pertanyaan}

1. Mengapa lama penyimpanan tidak signifikan dalam penelitian yang dilakukan?

2. Mengapa penambahan bentonit tidak signifikan dalam penelitian yang dilakukan, apakah perlu diaktivasi terlebih dahulu?

3. Daya simpan perlakuan tidak berbeda karena apa? 


\section{Jawaban}

1. Karena sebelum dilakukan penyimpanan pelet dalam kondisi yang baik, penyimpanan pelet dilakukan dalam kondisi anaerob sehingga terhindar dari kontaminasi lingkungan luar sekaligus menjaga kadar air dan kelembaban udara selama penyimpanan. Kondisi lingkungan yang baik memungkinkan bakteri Coliform tidak dapat bertahan hidup lama sehingga menyebabkan kematian.

2. Karena kemungkinan bentonit belum dilakukan aktivasi terlebih dahulu pada saat proses pengolahan sehingga fungsi bentonit tidak optimal. Bentonit sebelum digunakan harus mengalami pengaktifan terlebih dahulu karena dalam keadaan awal hanya memiliki kemampuan absorpsi yang rendah (Retnani et al. 2009).

3. Penyimpanan pada anaerob membuat bakteri tidak berkembang sehingga sudah menurun 